\title{
PERFIL DE MULHER CAMPONESA NO SUDESTE DO PARÁ *
}

Rosa Elizabeth Acevedo Marin**

\section{Introdução}

Quando se pretende elaborar o perfil sociológico de um grupo social, trata-se de descrever seus contornos, de forma precisa, identificando os elementos e as situações sociais compartilhadas, assim como as relações sociais e políticas num tempo e numa sociedade. A dificuldade de elaborar esse perfil reside em cruzar uma apresentação e uma reflexão sobre as biografias, trajetórias - neste caso, de mulheres com a sua "experiência de classe" ". Orientamos esta apresentação de algumas histórias de vida de

\footnotetext{
* Agradeço à Gutemberg Guerra os comentários esclarecedores sobre o 'perfil' da entrevistada.

** Socióloga, doutora em História, professora adjunta IV do Núcleo de Altos Estudos Amazônicos NAEA-UFPA.

${ }^{1} \mathrm{O}$ conceito de experiência de classe encontra-se em E. Thompson para quem esta é "determinada pelas relações produtivas dentro das quais os homens nascem - ou entram de modo involuntário". Temos uma discussão sobre sua formulação no trabalho de Hunt, que afirma que o historiador inglês dedicou-se ao estudo das "mediações culturais e morais" ou da "maneira como se lida com essas experiências materiais... de modo cultural". A segunda noção é a de "consciência", definida como "a maneira pela qual essas experiências (de relações produtivas) são manipuladas em termos culturais: incorporadas em tradições, sistemas de valores, idéias e formas institucionais”. (Hunt, 1992: 6-7).
} 
mulheres, buscando com os dados construídos traçar apenas alguns contornos de sua experiência.

Em julho do ano passado, realizamos entrevistas sobre os assentamentos na região de Marabá, de Curianópolis e de Eldorado de Carajás $^{2}$. No terreno visitamos assentamentos organizados pelo MST e pelo INCRA. Dos contatos estabelecidos em Marabá, o mais freqüente foi no Sindicato dos Trabalhadores Rurais daquela cidade, pois pretendíamos entender um conjunto de situações, entre elas as relações dessa organização com o MST e a forma como agiam junto aos assentados. Nessa entidade tivemos condições de ouvir depoimentos de mulheres, em profundidade o de uma militante do sindicato e do Partido dos Trabalhadores. É o que apresentamos neste paper para empreender um discurso exploratório com vistas a definir dois ângulos da mulher camponesa do sudeste do Pará - o da prática política e o das práticas econômicas.

Quase diariamente passávamos algumas horas no Sindicato à espera de um ou outro membro da diretoria. Neste ir e vir encontramos uma senhora. Foi um fato novo, pois encontrar mulheres freqüentando o Sindicato não constitui ocorrência quotidiana. O Tesoureiro do Sindicato apresentou-nos a Raimundinha Solyno, e durante esses dias conversamos, sem uso de gravador, registrando algumas falas, com a fidelidade que permite ouvir e escrever o que está sendo narrado. Os lugares de encontro foram diversos: o Sindicato, o restaurante, o ônibus. Num desses dias ela nos acompanhou na viagem até Brejo do Meio, onde nos despedimos, pois ela seguiu para sua "Fazenda Nova América", no lugar denominado Deus Quer, situado na Serra do Encontro. Ali vive há 10 anos com o marido ("O seu velho"); dois filhos adultos moram junto com ela e cria oito netos, dos 32 de que tinha conhecimento até julho de 1997. Ademais há outra pessoa em casa que a está ajudando.

Da maternidade tem duas tristezas. Uma filha é "louca" e desapareceu e a outra morreu em circunstâncias estranhas. Pensa-se que essa morte foi obra de pistoleiro.

\footnotetext{
${ }^{2}$ Durante a execução da pesquisa Estudo Comparativo de Estratégias de Sustentabilidade em Comunidades Rurais do Pará (Brasil) e Goa (Índia), que teve financiamento da UNESCO - Programa SulSul (julho 1997 a outubro 1998), tivemos a oportunidade de produzir os dados aqui discutidos.

${ }^{3}$ Eilson Gomes da Costa, cearense, apelidado de O Guarda.
} 


\section{Quem é essa mulher? A biografia}

Neste ponto é importante introduzir a biografia ${ }^{4}$ com a trajetória de vida e política de nossa entrevistada em Marabá. Algo como lembrar e parodiar a letra daquela música de Chico Buarque Quem é essa mulher que labora, sem descanso? Raimundinha move-se na denominada fronteira, onde é possível inserir e descrever atores, relações sociais e várias linhas e momentos de tensão e conflito. Percorremos primeiro, a ascendência dessa mulher de fronteira: o pai, de nome José Moretti, era um argentino com uma história política em grandes traços narrada por sua filha. Sabe que fugia, foi um perseguido político do governo de Rosas. Sua avó materna era uma índia Carajás. Também identifica o bisavô como escravo.

Acompanhou a família que veio de Goiás, de um lugar do atual Estado do Tocantins para Marabá. Ela foi migrante aos 9 anos de idade; mais ou menos na metade deste século estava chegando à Velha Marabá, onde cresceu e se fez mulher.

Marabá dos anos 50 "era só castanha. O mantimento: arroz̧, farinha, tudo vinha de Carolina on Imperatriz. A cidade tinha a rua da praia, onde estavam os comércios que recebiam a castanha". Raimundinha entrou criança no mundo do castanhal e lembra-se "dos seis meses que ficavam na cidade, durante o inverno e os outros seis, no verão que se mudavam para a 'praia'. Conhece desde esse tempo a família de "Nagib Amauri, mariscador e comerciante. Ele vendia carne e lingüiça e é o irmão de José Amaury que não teve castanhal”. Essa lembrança também se articula nas relações da família com os Amaury e o coronel João Anastácio de Queiroz.

De onde procedem os relatos da violência de Marabá presenciada por uma criança, por uma adolescente? Nessa memória foi retido o caráter de alguns atores da vida social e política de Marabá, o afloramento das rivalidades entre blocos de família: 'Do João Anastácio de Queiroz, dizia-

\footnotetext{
${ }^{4}$ É importante relembrar que, através da biografia de Raimundinha, buscamos relações dela com seu grupo e com a sociedade. Como esclarece Pereira de Queiroz, nos estudos sociológicos ou antropológicos, "não se trata de considerá-lo (o indivíduo biografado) isoladamente, nem de compreendê-lo em sua unicidade; o que se quer é captar, através de seus comportamentos, o que se passa no interior das coletividades de que participa. O indivíduo não é mais o "único"; ele agora é uma pessoa indeterminada, que nem mesmo é necessário nomear, é somente unidade dentro da coletividade. Todavia, em meu anonimato, contém o indivíduo num microcosmo as configurações que sua coletividade abarca, ao ordenar umas em relação às outras unidades, de que se compõem (sic) o grupo" (Queiroz, 1988: 24).

${ }^{5}$ João Anastácio de Queiroz foi Prefeito, na época do Intendente Magalhães Barata, durante 15 anos. Aparecia como proprietário de uma "gleba" que ia do Itacaiúnas ao Sororo.
} 
se que era justiceiro, era esse carnicifero (sic)". Raimundinha trabalhava na casa de Lorinha e convivia na cozinha com uma outra adolescente de 15 anos, de nome Rosinha. Lembra que a Lorinha batia nela. A "criada" de 15 anos havia sido roubada e estava presa na casa. "Essa menina torrava café,fritava toucinbo para fazer banha. Ela roubou e depois levou na casa de Alzira Mutran". Estava em curso uma vingança. Os Rego e Mutran, na política, eram rivais dos Queiroz. Junto com esse "roubo", dizia-se que Alzira Mutran "iria fazer bruxaria e que o outro candidato perderia, para favorecer o Mutra".

A figura de Lorinha também é associada à de uma justiceira. A Raimundinha a localizou nos quadros do PSD. Acrescenta informações sobre o mundo do trabalho onde ela própria estava inserida: "Os trabalhadores comiam na casa dela".

D. Raimundinha conheceu o tempo da castanha e fala por experiência dos "donos de castanhais" e ainda mais, por ter tratado com os políticos locais, pois "foi criada por políticos". Viveu na casa de vereadores. Era na casa de Lorinha Rego e na sua casa que se reuniam todos os políticos. Dessa casa saiu e "terminou de ser criada pela família de João Anastácio de Queiroz”. Sublinha esses dados para ressaltar o seu conhecimento da linhagem política de Marabá, onde aprendeu, por vivência, os matizes da política. Um cenário disputado, que até os anos 80 media-se pela extensão dos domínios. Raimundinha afirma que os "Queiroz tinham terras até no Burgo do Itacaiúna”. O tempo consagrou o poder da família Mutran, que, aos olhos desta mulher, era pequena na disputa de fortuna: "Hoje se fala somente dos Mutran, mas eles eram nada em relação aos negócios dos Queiroz que eram os grandes donos. Os Mutran eram donos disso que hoje é a Nova Marabá”. A família realizou investimentos na cidade de Marabá, adquirindo lotes urbanos, comércio de materiais de construção. Enquanto exercício de poder, fizeram igualmente uma guinada, de antigos donos de castanhais deslocam-se para a cidade, disputando o poder na Prefeitura e elegendo Vavá Mutran para esse cargo. Essa trajetória foi contínua e é seguida de perto por esta mulher .

Os políticos e "donos de castanhais" estão na sua memória de

\footnotetext{
${ }^{6}$ Esse sistema político foi estudado por Emmi (1987), que destaca nos anos 30/40 a figura de João Anastácio de Queiroz no cargo de Intendente municipal, representando os interesses de Deodoro de Mendonça. Enquanto os Mutram inserem-se nas estruturas de poder e firmam-se nos anos 50/ 60. José Queiroz Filho virá a ser Secretário do Sindicato dos donos de castanhais e membro da UDR nos anos 80. Agradeço à autora a leitura atenta que permitiu demarcar estes quadros.
} 
infância, de adolescente e, hoje, de mulher consciente dos poderes constituídos no sistema político local. Os nomes giram e estão presentes nos conflitos de ontem e de hoje. As famílias de Marabá, quer dizer, os grupos com controle sobre a terra são contados a dedo, sendo possível estabelecer nexos entre eles e a violência, marca da fronteira. Do grupo Tibirica, Raimundinha destaca o Sr. Nelito Almeida falecido, "era irmão de Tiribiça - Pai de João Almeida. No tempo de Sebastião Teresona, fazia parte dos que mandava matar os posseiros".

\section{Práticas políticas de uma camponesa}

A iniciação de Raimundinha em organizações ocorreu por volta dos anos 80, quando trabalhou no Movimento de Educação de Base e ela "ficou na área rural". O seu marido também participava dos movimentos dos posseiros. Raimundinha insistiu em dizer que, durante a guerrilha do Araguaia, ele foi um dos torturados pelo Exército. Dessa longa experiência, apenas fragmentada, nasce a Raimundinha camponesa, com projetos alternativos para permanecer e trabalhar na terra e, igualmente, a sindicalista, dirigindo uma série de ações no lugar onde mora.

De acordo com as informações do Sindicato, uma parte da gleba Cinzeiro (ou Projeto Cinzeiro) corresponde às de José Amaury (Serra do Encontro), outra, às de Zezé Mutran (onde está a vila Deus Quer) e a terceira, à Vila São João (área da antiga fazenda Tartaruga). Inclui ainda uma área do Castanhal Conquista e da Vila do Cândido, que era de José e Alice Silau Amaury. Nesse último trecho, essa terra foi ocupada em 1976. A entrada de posseiros na vila Deus Quer foi em 1983. A Raimunda ocupou um lote em 1987. No total, Cinzeiro reúne 192 famílias. Muitas pessoas saíram por doenças ("tinha muita malária na beira do Cinzeiro") e morte, de tal forma que na vila São João encontram-se apenas $4 \%$ das pessoas que entraram há 15 anos.

A produção da área é arroz, milho, feijão e banana. Alguns têm cabeças de gado. Na primeira fase de organização desse grupo, funcionava uma cantina criada pela cooperativa. Essa associação surge para fazer o 'grupo de arroz': cada sócio entregava dois sacos de arroz. Esses grupos foram formados nas experiências de comercialização de arroz promovidas pelo CAT (FATA e LASAT) a partir de 1989, e serviram de base para a fundação da Cooperativa Camponesa do Araguaia Tocantins - COOCAT.

A Associação dos Pequenos e Médios Produtores Rurais da Serra

${ }^{7}$ A vila Deus Quer fica a $52 \mathrm{~km}$ da cidade de marabá. 
do Encontro (APEMPRUSE) foi fundada em 1992. Entre os associados, 80 fizeram o financiamento para gado e cada um recebeu uma cabeça. Alguns fizeram plantios. O crédito foi no valor de $\mathrm{R} \$ 12.000,00$ para ser pago até o ano 2.001. Para pagar a dívida, alguns venderam o lote, com o dinheiro recebido saldam as dívidas e compram um lote em outro assentamento.

Raimunda tem 30 alqueires de terra. Já abriu cinco alqueires, o que significa que fez a derruba, limpou e plantou capim. Mantêm 25 alqueires de mata virgem, cinco alqueires são de pasto formado que está limpo e cercado. Desde 1987 vem abrindo 1/2 a 1 alqueire. Ela explica que abriram essa área só para comer; pois não há transporte e não dá para vender a produção. Normalmente faz o alqueire e pode chegar a tirar 10 a 15 sacos de arroz. Há três anos não "mexe com a mata" e somente está "faźendo para comer, pois não abriu mais terra". Tem, pois, três alqueires de arroz em "palhada", ou seja fica somente a palha do arroz e do milho por três anos. $\mathrm{Na}$ área já aberta planta milho, feijão, fava. Plantou 3000 pés de cupuaçu e 40 pés de mogno. Defina essa última plantação como uma herança, pois "é pra ficar e ele vai dar fruto". Também quer plantar o feijão "Andu". É um arroz que permite criar sombra e depois é cortado" Essa experiência agrícola é, ao seu ver, importante, pois veio do grupo do arroz - denominado COCAT - e evitou muita queimada.

Nesse discurso de uso e manejo do lote, compartilhado com o marido e filhos, ela não precisa exatamente qual sua contribuição e responsabilidade e se coloca fora de atividades definidas no campo masculino. Sobre a sua contribuição na economia da unidade, D. Raimunda disse que "a mulher trabalha na horta, onde tem alface, couve, maxixe, quiabo e que as hortas são canteiros”. Animada, aliás, anunciou seu projeto de fazer uma grande horta comunitária, que já tem antecedentes na criação de pequenos grupos que trabalham nos "viveiros comunitários".

O leque de problemas e de projetos que ela citou faz parte da agenda de uma sindicalista que é um reflexo das perspectivas do grupo. Desta forma, tratou dos problemas de irrigação para toda a área do Cinzeiro, onde existem áreas com falta de água, o que provocou a perda do plantio de cocos da praia, coco-da-baia nomes populares para o Cocus nucifera.

O problema da comercialização continua sendo o mais difícil a

${ }^{8}$ O Sindicato informou que na APEMPRUSE tem 236 famílias inscritas. 
enfrentar, pois os produtores não conseguem se ver livres dos atravessadores. "A cantina pequena que tem lá, o pessoal não entendeu. Eles não estavam entendendo como funciona a cantina. Ela nunca morreu”. A cantina não conseguiu ter transporte, nem capital de giro para comprar mais e vender para os inscritos. A Raimundinha concluiu: "Falta finanças para fazer um. trabalho sobre isso. Mas o Sindicato não tem transporte, não tem a cantina. O pessoal do Sindicato não tem como comprar. Alguém manda para o Sindicato um saco de arroz de feijão".

Diversos estudos mostram as relações dos comerciantes e usineiros com os agricultores. Os atravessadores compram o arroz por $\mathrm{R} \$ 13,00 \mathrm{a}$ saca de 60 quilos, isto dependendo da região. $\mathrm{O}$ atravessador chega com um caminhão e vai vender na cidade ao dono de usina . O preço sobe para $\mathrm{R} \$ 25,00$. O atravessador que compra na folha é o que paga o preço mais baixo, R \$ 5,00 ou até 7,00. Os atravessadores podem pagar com "rancho", e aí o preço do óleo, do açúcar, do café aumenta e é "uma exploração medonha". No peso do arroz, encontra o produtor várias "contas desvantajosas", pois é "descontada a casca, a diferença do arroz já seco, a palha e a quebra do arroz". O dono da fábrica de arroz vai ficar com o "cuim" ("uma palha de arroz bem fininha que serve para alimento do porco"). Também fica com o "xérem" que é usado para fazer massa de arroz, depois de moído. O usineiro ainda desconta a gasolina ou o frete, o desgaste da máquina e a palha do arroz. Essa cadeia do beneficiamento e da comercialização constitui um gargalo, e D. Raimunda apontou: "Se tivéssemos a máquina, tudo caminharia bem para nós. Essa máquina de arroz que existe é particular, só para limpar dez sacas cobram $\mathrm{R} \$ 0,10$ por quilo. O usineiro fica com esse percentual do arroz.

Em 1987, Raimundinha abriu a primeira roça na fazenda Nova América. Vendeu muito para atravessador. Em 1994, teve muito arroz e não sabe quanto vendeu, tudo era para fazer o rancho. De 100 sacos somente fica com 30 sacos. O resto é para comprar roupa, o "ranchincho", os remédios. "Quando tem banana e vende é salvaguarda da gente". Naquela semana, D. Raimunda havia carregado um cacho de banana para vender em Morada Nova. Negociou a venda e, no outro dia, passava pelo dinheiro.

\footnotetext{
${ }^{9}$ No Sindicato tivemos noticias das grandes usinas localizadas na Nova Marabá.

${ }^{10}$ Cuim é um subproduto do processo de beneficiamento mecanizado do arroz. É uma farinha fina, utilizada na fabricação de bolos e mingaus caseiros, assim como na alimentação de animais de pequeno e médio porte (aves e suínos).

${ }^{11}$ O xérem é um subproduto do processo de beneficiamento mecanizado do arroz ou do milho. São os grãos quebrados utilizados na alimentação humana como cuscuz, bolos e mingaus ou na alimentação de animais de pequeno porte.
} 
Isso significa que ela interage no mercado, em condições de responsabilidade semelhantes às dos homens.

Máquinas de beneficiamento, transporte em mãos da Associação ou do Sindicato formam as demandas desse grupo. Da mesma forma que aguardam a saída do PROCERA, para com ele conseguir o crédito. Crédito não é linguagem nova para essa mulher e suas congêneres. Existe um freio apenas quando são elas que pretendem apresentar-se como beneficiárias. Falta o documento da terra, garantia do crédito.

De fato, esse retrato da mulher camponesa mostra claramente sua versatilidade. As mulheres organizam, executam e programam sozinhas ou compartilhando com os membros do sexo masculino das famílias uma parte importante dos trabalhos nas unidades familiares. Neste sentido não são apenas auxiliares, nem a elas está reservado o espaço da casa.

\section{Práticas políticas de uma mulher camponesa}

Girando em torno dessa noção de experiência, identificamos, como primeira prática a descrever sobre a mulher do campo, os pontilhados de sua participação política e traçamos um paralelo entre a trajetória de Raimundinha nos anos 80 e a dos anos 90. Aqui o interesse não é apenas questionar o fato mais visível de ausência da mulher rural na política, mas encontrá-la no cenário do campo paraense, nas áreas de fronteira, envolvida em situações de conflito. Os lugares dessa participação são semelhantes entre homens e mulheres - sindicato, associações, comunidades eclesiais. Certamente parece mais restrita no caso da mulher: sua maior atuação desenvolve-se nas associações e nas comunidades de base e se afunila no envolvimento da vida sindical ou partidária. Raimunda não começou sua experiência de participação no Sindicato. A sua "formação", e em especial sua prática, começa em comunidades de base, que tiveram forte participação nas lutas agrárias da década de 80. Companheiros dessa etapa, vários agricultores organizaram-se em oposição sindical, e Raimundinha vai acompanhá-los na fase mais ativa de discussão sobre as estratégias para tomar diretorias comprometidas com o poder da oligarquia, o Sindicato de Trabalhadores Rurais de Marabá.

O Sindicato Rural no Brasil mostra forte presença masculina, e Marabá não é exceção. Trata-se de uma divisão de competência entre os gêneros que mostra alguns sinais de debilitamento, entretanto as formas de participação reservam maiores espaços ao homem. Geralmente, a 
presidência, a vice, a secretaria e conselhos são encabeçados por homens, salvo os casos em que alguma mulher conquista uma secretaria. O significado dessa matriz de ausência e presença não é outro que o reflexo de posições e espaços públicos masculinizados.

Nossa entrevistada em Marabá, depois de uma intensa participação no Sindicato, em um trabalho que se prolongou por dez anos para "tomar o sindicato dos pelegos", hoje ocupa o comando da Secretaria das Mulheres. Essa seção, junto com as Secretarias Agrícola e a de Meio Ambiente e Social representa parte do organograma mais novo do Sindicato. Essa divisão constitui uma área de trabalho em que se processam as novas experiências para as sindicalistas, o conjunto das mulheres do campo e a própria organização. D. Raimundinha adota como princípio: "trabalhar com a mulber na consciência, no todo com o sindicalista".

Que questões estão orientando essa observação? Trata-se de uma situação de exclusão das mulheres das estruturas de poder e de mando do sindicato, que começa pela própria identificação profissional. $\mathrm{Na}$ declaração de ocupação, feita em documentos cartoriais, como por exemplo na certidão de casamento ou de residência, a mulher não aparece como trabalhadora na roça, lavradora. Adota-se a ocupação de serviços domésticos. Aliás, esse tipo de declaração tem sérias implicações nos seus direitos trabalhistas.

Podemos situar aqui práticas e atos legais que simplesmente dificultam a identificação da mulher como trabalhadora direta e, via de regra, com grande responsabilidade na sobrevivência de sua família. Desencadeia-se uma série de restrições a partir de uma declaração de ocupação: a concessão, em seu nome da terra, a obtenção de crédito. Vejamos alguns detalhes que não estão rigorosamente comprovados neste trabalho, mas que foram objeto de Observação pelas entrevistadas: qual o número de mulheres que, na condição de chefes de uma unidade familiar, possuem títulos de terra? Esses dados e situações concretas podem estar mascarando o papel da mulher, e, no plano do direito podemos reapresentar a necessidade de um reconhecimento legal. Parece que as notificações deste tipo - registro, certidões - são elaboradas para aplicar à propriedade um princípio de neutralidade. A propriedade não é masculina, nem feminina, mas sem dúvida, o proprietário tem uma identificação de gênero que funciona, nesses casos, como uma distinção com sinais de marginalização ou de dominância. 
Para os cinco municípios do sudeste do Pará, o Cadastro de Imóveis Rurais (INCRA/ ano 1995) relaciona um pequeno número de imóveis declarado em nome de mulheres: de um total de 3.211, são 317 imóveis, o que representa menos de $10 \%$. Nesse relatório apenas três declarações referem-se a empresas, e a maioria dos declarantes são do sexo masculino. Esse dado permite estabelecer relações interessantes sobre os mecanismos que permitem ou restringem o acesso de mulheres a terra e especialmente sobre as condições em que este acesso foi ou está sendo possibilitado.

Quando constatamos a redução do grupo feminino nessa posição legal, podemos inferir que várias regras de propriedade, formando um sistema de princípios diferentes, mas combinados, estão vigorando. A forma de apropriação e o uso do território refletem no campo brasileiro uma estrutura de parentesco e suas regras. A unidade básica protegida pelo instrumento legal, seja a Constituição de 1988, seja o Estatuto da Terra, a família, e este principio está explicitamente declarado nos programas de distribuição da terra. Existe, pois, um sistema de classificação anterior à decisão de atribuir a terra. A chefia da família no meio rural é tradicionalmente dos homens, fato reforçado ideologicamente na sociedade, mesmo que essa posição hierárquica não corresponda integralmente às mudanças de papéis de mulheres e homens e nem às formas das relações sociais. Esse modelo representa a família monogâmica, estável, quando se sabe que nas áreas de fronteira esse quadro é diferente, pela formação de novas uniões, pela ausência da figura masculina por mobilidade para o trabalho assalariado nas fazendas ou no garimpo, por morte ${ }^{12}$ e por situações em que famílias chefiadas por mulheres (as denominadas "famílias de mulheres" da literatura antropológica, pleiteiam o reconhecimento de direitos.

Mas o reconhecimento do direito à terra reflete uma distribuição desigual entre homens e mulheres, observada igualmente entre tamanhos de propriedade e grupos sociais. Desta forma, tornam-se transparentes as relações de dominação entre os sexos e entre grupos sociais existentes no campo paraense. Vejamos a distribuição por tamanho da terra.

\footnotetext{
${ }^{12}$ No campo maranhense e no Pará, o movimento social das Viúvas de Camponeses é interessante por mostrar alteração das situações concebidas estaticamente. Elas se organizam reivindicando direitos humanos, por exemplo o acompanhamento dos processos jurídicos sobre as vítimas e direitos sociais, como indenizações, pensões, reconhecimento da terra em seu nome.
} 


\begin{tabular}{|c|c|c|c|c|c|c|}
\hline & Marabá & Curionópolis & Parauapebas & $\begin{array}{l}\text { Eldorado } \\
\text { do Carajás }\end{array}$ & $\begin{array}{l}\text { Agua } \\
\text { Azul }\end{array}$ & Total \\
\hline Minifúndio & 51 & 2 & 138 & 7 & 16 & 214 \\
\hline $\begin{array}{l}\text { Pequena } \\
\text { propriedade }\end{array}$ & 25 & 5 & 29 & 2 & 7 & 68 \\
\hline $\begin{array}{l}\text { Media } \\
\text { propriedade }\end{array}$ & 8 & 1 & 4 & 1 & 2 & 16 \\
\hline Grande & 4 & - & 8 & - & 1 & 13 \\
\hline $\begin{array}{l}\text { Não } \\
\text { Classificado }\end{array}$ & 4 & - & 2 & - & 1 & 6 \\
\hline Total & 92 & 8 & 181 & 10 & 27 & 317 \\
\hline
\end{tabular}

O levantamento de dados dos Cadastros de Imóveis Rurais ${ }^{13}$ dos municípios de Marabá, Curionópolis, Eldorado do Carajás, Parauapebas, Água Azul do Norte identifica 3.211 propriedades, e destas somente 317 estão cadastradas em nome de mulheres, o que representa menos de $10 \%$. Desse número, 224 eram minifúndios, 68, pequenas fazendas, 16, fazendas médias, 13, fazendas grandes. O total de grandes propriedades é de 171, destas 13 foram declaradas em nome de mulheres e seis não são especificadas. No conjunto, os minifúndios (áreas com menos de 70 ha) formam o grupo mais importante na categoria dos imóveis -214 . O total de declarações de imóveis enquadrados como minifúndios foi de 2.003, destes 214 em nome de declarantes femininos. Essa distribuição reflete regras sociais provenientes de estruturas tradicionais em que os homens são tradicionalmente reconhecidos como cabeças de família. Esse modelo nem sempre corresponde às mudanças de papéis de mulheres e homens na estrutura social. A fluidez na formação de alianças, a migração masculina e unidades familiares não exclusivamente monogâmicas não estão em consonância com uma chefia de homens. Em alguns casos, as chefias femininas são reconhecidas por sentença judicial.

Em 1981, quando conheci o assentamento Ariquemes, em Rondônia, ouvimos de mulheres, algumas delas viúvas, que o INCRA não concedia facilmente terras. Dona Valda, uma viúva com seis filhos menores, revoltavase por não ter tido acesso à terra. Certamente, foi uma lacuna da pesquisa o fato de não ter sido indagado aos técnicos do INCRA os motivos para tal arbítrio.

\footnotetext{
${ }^{13}$ Os Cadastros de Imóveis Rurais foram consultados no INCRA de Marabá.
} 
Em Marabá coletamos informações sobre a situação de viúvas nas áreas, situação que é bastante freqüente. Hoje contam-se algumas viúvas que têm a terra. Surgem duas perguntas: como esse grupo de mulheres envolvidas em situação de conflito de terra experimenta a violência e de que recursos elas dispõem para lhe fazer frente? A entrevistada comentava que, em áreas em conflito, os fazendeiros e capangas perseguem os homens e quando "as mulheres são sozinhas a perseguição é grande". Concretamente, Raimundinha estava introduzindo três histórias de vida. A primeira, o drama de Maria do Índio, que vive no assentamento Cinzeiro. "Mataram o Índio, seu marido, foram pistoleiros mandados por Marlon. Ela ficou na terra. Ela trabalha broca, derruba e planta. Tinha somente uma filha. Depois ela vendeu a terra, vendeu o lote, depois vendeu e andava empregada". Maria do Índio teve medo e se "desencantou", pois era muito difícil continuar trabalhando na terra. De alguma forma, não se libertou do espectro da violência vivida e desistiu do lote. A segunda é a história de Lúcia: "ela não tem marido, trabalha com um filho, o outro é doente. Ela tem três alqueires e vive na Conquista, que é continuação do Cinzeiro. Ali brigou com o Marlon que não queria que ela entrasse na sobra de terra". A terceira é a "Morena, ela também é viúva e tem dificuldade pra ficar na terra".

Uma etnografia dos conflitos sugere que as pressões psicológicas e o medo têm um alvo certo nas mulheres. Não raro, fazendeiros e capangas escolhem as esposas e as mães para deixar recados, fazer ameaças e mostrar força perante os homens. Com isto esperam poder alcançar o objetivo principal: a saída da terra de trabalhadores perseguidos e já sabidamente amedrontados.

Que força intervém para proteger as mulheres em situação de perseguição? No campo institucional, os conflitos escapam praticamente a qualquer controle. As mulheres podem buscar a policia, mas dificilmente mostram confiança na sua ação. $\mathrm{O}$ que se organiza como proteção depende da articulação do grupo e de entidades de apoio e defesa: o sindicato, a associação e algumas ONGs. As coragens reveladas por algumas mulheres vitimam da violência patenteia também o vazio de qualquer força organizada pelo Estado com condições de controlar, dar proteção e mediar, se for o caso, na negociação de respeito à vida e dignidade dos mais fracos envolvidos nos conflitos.

As experiências relatadas de organização para as ocupações de terra também ajudam a perceber uma posição ativa das mulheres. Elas são 
protagonistas da luta pela reforma agrária, pelo fim da impunidade e contra a violência.

Esse ângulo leva-nos a refletir sobre as interações entre a mulher do campo e as instituições públicas e a causa da intransigência nos relacionamentos. Dificilmente, as instituições voltadas para a um trabalho no campo sublinham a presença da mulher. Assim, os técnicos da SAGRI, EMATER, etc. buscam identificar o trabalhador e não a trabalhadora, pois ela não existe no universo de classificações dos técnicos.

As agências bancárias podem acumular outras razões formais, mas em principio o crédito é atribuído ao trabalhador rural identificado profissionalmente. Para os pesquisadores na área da Sociologia Rural ou dos Processos Agrários, esse tipo de relações é pouco explorado e temos poucas evidências fatuais para saber por que menos mulheres têm crédito. Apesar de se tratar de uma realidade demográfica (há mais homens do que mulheres chefiando unidades camponesas), este dado não é totalmente convincente. Esta orientação nos levaria a insistir em direitos e eqüidade no tratamento da mulher e do homem trabalhador na roça a partir de situações e relações sociais concretas - a mulher está inserida em relações assalariadas ou, na maior parte dos casos na Amazônia, é responsável por uma unidade familiar camponesa.

Em 1994, o Sindicato de Trabalhadores Rurais apresentou uma reivindicação ao INSS: a aposentadoria das mulheres camponesas. O problema tinha início com a declaração que consta da certidão de casamento, um dos documentos para introduzir essa solicitação. Na maioria dos casos, as mulheres declararam-se ou foram identificadas como domésticas e não como agricultoras. Argumentava Raimunda: "A mulher trabalha na roça e quando sai no cartório é doméstica. Não podia ser lavradora. Somente tem o direito quem tem declaração no documento". Em 1996, conseguiram poder introduzir junto ao INSS o pedido de aposentadoria com uma declaração do Sindicato. Raimunda foi um dos membros do Sindicato a empreender esse tipo de ação reivindicativa.

Outro aspecto vinculado à inserção da mulher do campo em universos de poder reservados aos representantes do sexo masculino está relacionado à participação em esferas políticas da administração local. Se nas cidades é pequeno o número de mulheres vereadoras, o número das que têm origem rural ou vivem nos assentamentos chega a ser insignificante.

Raimundinha foi candidata a vereadora no ano de 1996 pelo Partido dos Trabalhadores. A decisão teve um custo pessoal elevado. O Sindicato 
não deu apoio, pois alegava que a sua candidatura somente foi lançada para ajudar Bernardete Tencaten . Mas, em sua opinião, o desentendimento deveu-se à filiação ao P.T., que não coincidia com as opções dos outros membros do Sindicato. A campanha custou muito: "Gastou 100 reais e quase perdeu o marido. Perdeu as galinhas, e eram cinqüenta, e um porco pois todos comeram as galinhas, os pintos e o porco".

Raimundinha candidatou-se para ajudar o partido. Obteve 77 votos. Esse resultado é contestável, pois na sua opinião houve muita urna impugnada em que ela contava com votos. Em Abel Figueiredo, foram 33 votos, em Brejo do Meio, 10 votos e no bairro da Liberdade, de 15 a 20 votos. O lema de sua campanha revelava sua vivência: "Raimundinha: mulher de luta: campo e cidade".

Entre outras contribuições desta mulher para o seu grupo, está o repasse do seu saber prático sobre medicina. Ela "aprendeu a fazer remédio, medicina caseira, para fígado, sangue, anemia, derrame cerebral..." e, no assentamento em que vive, ajuda os que a solicitam em matéria de saúde. Os projetos apresentados ao Sindicato de fato expõem uma visão das situações sociais, econômicas, políticas e jurídicas que diferenciam os gêneros no mundo rural.

\section{Conclusão}

A construção desse contorno de mulher camponesa procede de uma elaboração preliminar. Apenas alguns direitos começam a se conjugar no feminino: direito à declaração consistente da ocupação de agricultora e ao seu registro em carteira de trabalho; certificados de casamento e outros documentos que dêem reconhecimento legal às mulheres; direito e estímulos para o registro de terras por chefias mulheres; direito à aposentadoria; direito à participação política e representação plena em sindicatos, associações e movimentos. Trata-se em todo caso de passagem do direito formal, reconhecido, para práticas em que se constate a igualdade de oportunidades para as mulheres.

De acordo com as experiências sociais específicas das mulheres camponesas do sudeste do Pará, aqui insistindo sobre os conflitos pela terra e a violência, por exemplo, percebe-se que elas têm aprofundado e renovado os campos de atuação política e econômica. Articulam nos seus discursos as relações de exploração e de opressão nos espaços produtivos,

\footnotetext{
${ }^{14}$ Bernardete Tencaten, vereadora eleita pelo Partido dos Trabalhadores, é professora de $2^{\circ}$ Grau e foi Secretária de Educação do Município e ainda Diretora da Fazendinha.
} 
como também socializam as práticas quotidianas de organização, de resistência e solidariedade.

A leitura da biografia de Raimunda Solyno mostra, ao lado de formas mais ou menos veladas de discriminação no interior da organização sindical, uma positiva conquista de espaços na medida em que a estrutura sindical passa por uma atualização dos seus programas de atividade, e com isto insere plataformas de lutas das sindicalistas e das camponesas.

A construção de novas relações de gênero passa por um desmontar das diversas estruturas organizativas, jurídicas-políticas e ideológicas que no campo e na cidade freiam a evolução da mulher.

\section{Referencias bibliográficas}

ACEVEDO MARIN, Rosa Elizabeth e GUERRA, Gutemberg (1994) Trabalhadores rurais: a cidadania via Seguridade Social. Belém, Paper do NAEA, n 28 .

EMMI Marília Ferreira, ACEVEDO, Rosa (1997) De posseiros a assentados. In. COELHO, Maria Célia Nunes e COTA, R. (org.) Dez anos da Estrada de Ferro Carajás. Belém.

EMMI, Marília Ferreira (1987). A oligarquia do Tocantins e o dominio dos castanhais. Belém: NAEA/ CFCH/UFPA.

HUNT, Lynn (1995). A Nova História Cultural São Paulo, Martins Fontes.

QUEIROZ, Maria Isaura Pereira de (1988). Relatos orais: do "indizível” ao "dizível". In SIMGON, Olga de M. Von. Experimentos com História de Vida. Itália-Brasil, São Paulo, Vértice.

THOMPSON, Eduardo. A formação da classe operária na Inglaterra. São Paulo. 


\section{Siderurgia e Carvoejamento na Amazônia}

Drenagem energético-material e pauperização regional

Maurílio de Abreu Monteiro 1998

Analisa a gênese e desenvolvimento de indústrias siderúrgicas na Amazônia oriental brasileira, indicando que a realidade que se desenha, em decorrência da operação destas plantas industriais da operação destas plantas industriais, é distinta da que apontava o planejamento estatal. A demanda de carvão vegetal consolida-se como o principal vínculo das indústrias com as dinâmicas sociais, econômicas e ecológicas da região. Os empreendimentos, marcados por sua baixa eficiência energética, imprimiram novos ritmos e mecanismos de transferência de matéria e energia da região. Essas transferências, além de implicações sobre o mundo biofísico, do ponto de vista social, não tem favorecido a edificação de estruturas sociais complexas como as edificadas em algumas sociedades da Europa e América do Norte.

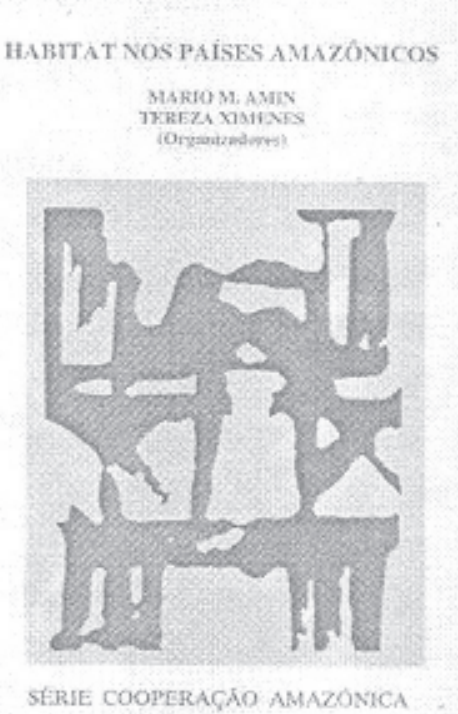

20

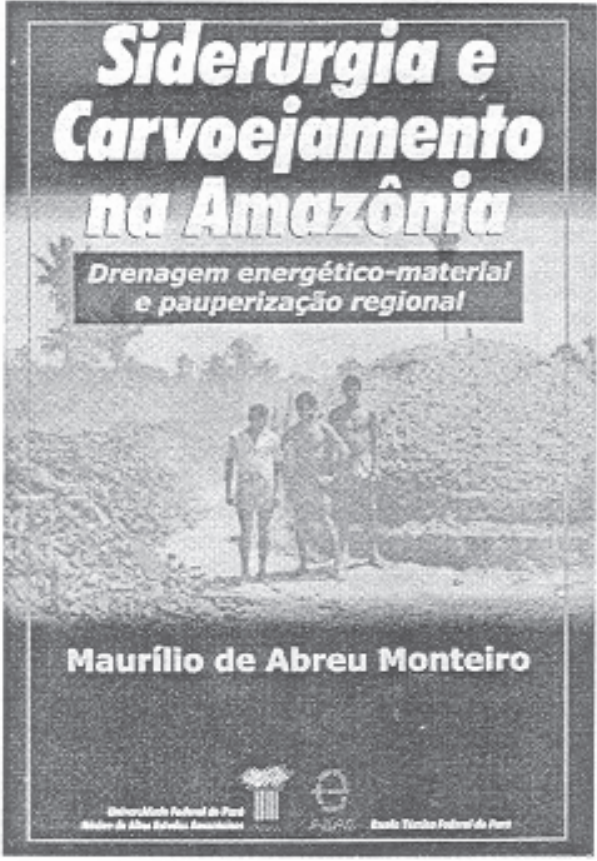

Habitat nos Países Amazônicos Mário M. Amin e Tereza Ximenes (Orgs.) 1998

Discutir os graves problemas que afetam o habitat na grande maioria nas cidades da Pan-Amazônia foi o objeto do III Curso Internacional em Política Científica e Tecnológica para a Amazônia. Esta coletânea reúne parte dos trabalhos apresentados pelos alunos no final do curso na tentativa de esclarecer os principais problemas que afetam as áreas urbanas e as condições sub-humanas de moradia em que convivem milhares de pessoas na Pan-Amazônia. A falta de vinculação destes fatores às políticas de planejamento urbano influi negativamente na qualidade de vida da população, levando as cidades a uma condição de insustentabilidade. Os artigos discutem o crescimento desordenado nas cidades, a deficiência na implementação do planejamento urbano de forma a apontar caminhos que levem a modificar as condições urbanas e habitacionais e ambientais. 